\title{
INHALED NITRIC OXIDE IN THE MANAGEMENT OF PERSISTENT PULMONARY HYPERTENSION OF THE NEWBORN: A META-ANALYSIS
}

\author{
Carlos Augusto Cardim de Oliveira, Eduardo J Troster and Crésio R Pereira
}

RHCFAP/3017

OLIVEIRA CAC et al. - Inhaled nitric oxide in the management of persistent pulmonary hypertension of the newborn: a metaanalysis. Rev. Hosp. Clín. Fac. Med. S. Paulo 55 (4):145-154, 2000.

Objectives: To evaluate the use of inhaled nitric oxide (NO) in the management of persistent pulmonary hypertension of the newborn. Methods: Computerized bibliographic search on MEDLINE, CURRENT CONTENTS and LILACS covering the period from January 1990 to March 1998; review of references of all papers found on the subject. Only randomized clinical trials evaluating nitric oxide and conventional treatment were included. Outcomes studied: death, requirement for extracorporeal membrane oxygenation (ECMO), systemic oxygenation, complications at the central nervous system and development of chronic pulmonary disease. The methodologic quality of the studies was evaluated by a quality score system, on a scale of 13 points. Results: For infants without congenital diaphragmatic hernia, inhaled NO did not change mortality (typical odds ratio: $1.04 ; 95 \%$ CI: 0.6 to 1.8 ); the need for ECMO was reduced (relative risk: 0.73 ; $95 \%$ CI: 0.60 to 0.90$)$, and the oxygenation was improved (PaO 2 by a mean of $53.3 \mathrm{~mm} \mathrm{Hg}$; 95\% CI: 44.8 to 61.4; oxygenation index by a mean of -12.2 ; 95\% CI: -14.1 to -9.9). For infants with congenital diaphragmatic hernia, mortality, requirement for ECMO, and oxygenation were not changed. For all infants, central nervous system complications and incidence of chronic pulmonary disease did not change. Conclusions: Inhaled NO improves oxygenation and reduces requirement for ECMO only in newborns with persistent pulmonary hypertension who do not have diaphragmatic hernia. The risk of complications of the central nervous system and chronic pulmonary disease were not affected by inhaled NO.

DESCRIPTORS: Nitric oxide. Newborn. Pulmonary hypertension. Extracorporeal membrane oxygenation (ECMO). Meta-analysis.

At birth, a disturbance of oxygenation leads to persistence of elevated pressure of the pulmonary circulation. Some arteries do not have a complete vasodilation, and others remain closed. Gersony ${ }^{1}$ described and named this syndrome persistence of fetal circulation.

Persistent pulmonary hypertension of the newborn (PPHN) is the common final pathway of pathologic conditions of circulatory and respiratory systems, including: respiratory distress syndrome, pneumonia with or without sepsis, pulmonary hypoplasia associ- ated with congenital diaphragmatic hernia and cardiac malformations. The increased vascular tone of pulmonary circulation persists even after the precipitating insult is removed. A higher pressure of the pulmonary artery leads to right-to-left shunting at the ductus arteriosus and/or foramen ovale, resulting in hypoxemia. Pulmonary parenchymal disease intensifies the uneven

From the Department of Pediatrics, Hospital das Clínicas, Faculty of Medicine, University of São Paulo. ventilation-perfusion ratio, which worsens the hypoxemia, increasing vasospasm $^{2-11}$.

The true incidence of PPHN is unknown because of non-uniform diagnostic criteria and the lack of systematic population-based studies. The described ratio ranges from 1 in 500 to 1 in 1400 live births, and morbidity is expressive, including neurological deficits and chronic pulmonary disease. PPHN is one of the most serious illnesses in newborn intensive care units $^{3,11-14}$.

The conventional treatment of 
PPHN includes: optimized ventilation with high fractions of inspired oxygen, induced respiratory and metabolic alkalosis, systemic vasodilators, hemodynamic support, correction of metabolic disorders, and the maintenance of a quiet environment ${ }^{15-20}$.

Nitric oxide is a free amphiphilic radical that acts as an intracellular and intercellular messenger, increasing the levels of c-GMP, which reduces the intracellular concentration of calcium, inducing vasodilation ${ }^{21,22}$.

Although the infusion of vasodilator agents has been shown to decrease pulmonary vascular resistance, its use is limited because of a concomitant decrease in systemic vascular tone, worsening the intrapulmonary shunt. The high affinity of NO to ferrous ion heme proteins results in its rapid inactivation by blood hemoglobin, giving to inhaled NO the property of selectivity to the pulmonary vascular bed ${ }^{22-27}$.

Clinical evidence has demonstrated that inhaled NO improves oxygenation in PPHN, but until now, trials have been too small to give reliable answers. The outcomes measured are not meaningful regarding mortality or quality of life, but rather are meaningful regarding surrogate outcomes like oxygenation $1^{4,28}$.

The objective of this review was to estimate more precisely the effects of inhaled NO in the management of PPHN.

\section{METHODS}

Study Identification: All clinical trials concerning NO and PPHN published from January 1990 to March 1998 were retrieved. This pool of studies was identified by cross-referencing the following medical subject heading terms using MEDLINE, CURRENT CONTENTS and LILACS: nitric oxide and infant; nitric oxide and newborn; nitric oxide and pulmonary hyperten- sion; pulmonary hypertension and infant; pulmonary hypertension and newborn. In addition, we reviewed manually the reference lists of each retrieved article obtained from the electronic databases, from other non-systematic reviews, and from congress chronicles. Only randomized clinical trials published in English, French, Spanish, and Portuguese were selected. We excluded incomplete studies and those from the same authors with the same population.

Study Population: Term ( $>37$ weeks of gestational age), or near term $(>34<37$ weeks of gestational age) newborns $(<28$ days of age at the beginning of the study) with hypoxemia and diagnosis of PPHN done by echocardiography were studied. Infants with intracardiac shunting due to structural heart disease (except ductus arteriosus) were excluded.

Interventions: The treated group received administration of inhaled NO by tracheal cannula. The control group was managed with conventional treatment.

Outcomes: Death, requirement for ECMO, systemic oxygenation, disturbances of the central nervous system (hemorragic disorders and convulsions), and development of chronic pulmonary disease during hospitalization were the outcomes studied.

Assessment of methodologic quality: The quality pattern of each study was assessed according to the Heyland score system ${ }^{30}$, with a maximum of 13 points.

Data analysis: Using the REVIEW MANAGER software, version 3.1, The Cochrane Collaboration, March 1998, data were combined to estimate, for categorical outcomes, the typical odds ratio, relative risk, relative risk reduc- tion, absolute risk redution and number needed to treat. Outcomes were measured on a continuous scale, and typical estimates for weighted mean difference were calculated, as well as their correspondent $95 \%$ confidence intervals. The heterogeneity of treatment effects across the studies was ascertained by a chi-square analysis, using the null hypothesis that results were similar, where $p>0.05$ for the test of homogeneity is consistent with the assumption that differences in study results are due to chance. Relative risk, and not odds ratio, was calculated if the outcome rate measured was higher than 0.2 .

\section{RESULTS}

Study selection: From January 1990 to March 1998, 261 publications were found that dealt with $\mathrm{NO}$ and PPHN. Eight randomized clinical trials fulfilled the inclusion criteria. The characteristics of these studies are described in Table 1.

The meta-analysis of results for infants without congenital diaphragmatic hernia included seven studies (548 newborns). Only two trials were selected for meta-analysis for infants with congenital diaphragmatic hernia (70 newborns).

Validity criteria and quality score of selected clinical trials are listed in Table 2.

The tests for homogeneity were non-significant, meaning homogeneous results in all analyses, except for "oxygenation index at $30 \mathrm{~min}$ ".

\section{PPHN without congenital diaphrag- matic hernia}

\section{A) Death during hospitalization.}

The meta-analysis included 5 studies (513 newborns) ${ }^{30,32,34,36,37}$. There were $31(11 \%)$ deaths in the NO group, and $26(12 \%)$ in the control group. There 
Table 1 - Characteristics of selected clinical trials.

\begin{tabular}{|c|c|c|c|c|c|}
\hline $\begin{array}{l}\text { Authors/year } \\
\text { (reference) }\end{array}$ & Multicentric & $\begin{array}{l}\text { Study } \\
\text { Population }\end{array}$ & $\begin{array}{l}\text { Gestational } \\
\text { age(weeks) }\end{array}$ & $\begin{array}{l}\text { Hypoxemia and } \\
\text { Mechanical Ventilation }\end{array}$ & $\begin{array}{l}\text { Co-interventions: } \\
\text { Surfactant and/or } \\
\text { HFOV a }^{\text {a }}\end{array}$ \\
\hline Barefield ${ }^{30}$ & No & $17^{\mathbf{b}}$ & $>35$ & Yes & Not Accepted \\
\hline Cornfield ${ }^{31}$ & Yes & 23 & Mean:37,3 $\mathbf{c}$ & Yes & Not Accepted \\
\hline Davidson 32 & Yes & 155 & $>37$ & Yes & Not Accepted \\
\hline Day $^{33}$ & No & 22 & $-\mathbf{c}$ & Yes & Accepted \\
\hline NINOS $^{34}$ & Yes & 235 & $>34$ & Yes & Accepted \\
\hline NINOS ${ }^{35}$ & Yes & $53^{d}$ & $>34$ & Yes & Accepted \\
\hline Roberts ${ }^{36}$ & Yes & 58 & $>37$ & Yes & Accepted \\
\hline Wessel ${ }^{37}$ & Yes & 49 & $>34$ & Yes & Accepted \\
\hline
\end{tabular}

a High frequency oscillatory ventilation

b Population studied 24, but only 17 were randomized

c Minimal gestational age not mentioned

d Study interrupted because of suggestion of worse outcome

Table 2 - Methodologic quality assessment of eight selected trials ${ }^{\mathrm{a}}$.

\begin{tabular}{|c|c|c|c|c|c|c|c|c|}
\hline $\begin{array}{l}\text { Author/yr } \\
\text { (reference) }\end{array}$ & $\begin{array}{c}\text { Barefield } \\
1996^{30}\end{array}$ & $\begin{array}{c}\text { Cornfield } \\
1997^{31}\end{array}$ & $\begin{array}{c}\text { Davidson } \\
1998^{32}\end{array}$ & $\begin{array}{c}\text { Day } \\
1998^{33}\end{array}$ & $\begin{array}{l}\text { NINOS } \\
1997^{34}\end{array}$ & $\begin{array}{l}\text { NINOS } \\
1997^{35}\end{array}$ & $\begin{array}{l}\text { Roberts } \\
1997^{36}\end{array}$ & $\begin{array}{l}\text { Wessel } \\
1997^{37}\end{array}$ \\
\hline Randomization & 2 & 2 & 2 & 2 & 2 & 2 & 2 & 2 \\
\hline Blinding & 1 & 1 & 1 & 1 & 1 & 1 & 1 & 0 \\
\hline Analysis & 2 & 2 & 2 & 2 & 2 & 2 & 2 & 2 \\
\hline Patient selection & 1 & 1 & 1 & 1 & 1 & 1 & 1 & 1 \\
\hline $\begin{array}{l}\text { Comparability of } \\
\text { groups at baseline }\end{array}$ & 1 & 1 & 1 & 0 & 1 & 1 & 1 & 1 \\
\hline Extent of follow-up & 1 & 1 & 1 & 1 & 1 & 1 & 1 & 1 \\
\hline Treatment protocol & 1 & 1 & 1 & 1 & 1 & 1 & 1 & 1 \\
\hline Co-interventions & 1 & 1 & 1 & 1 & 1 & 1 & 1 & 1 \\
\hline Crossovers & 2 & 1 & 1 & 2 & 2 & 1 & 2 & 2 \\
\hline TOTAL & 12 & 11 & 11 & 11 & 12 & 11 & 12 & 11 \\
\hline
\end{tabular}

${ }^{\text {a }}$ Score system according to Heyland ${ }^{29}$.

was no difference in mortality between groups (odds ratio: $1.04 ; 95 \%$ CI: 0.59 to 1.82) (Table 3; Fig. 1).

B) Requirements for extracorporeal membrane oxygenation (ECMO). Five studies ${ }^{30-32,34,36,37}$ were selected, including 537 newborns. Fewer patients from the NO group needed ECMO, 101/305 (33\%), compared to $115 / 232(50 \%)$ controls (relative risk: 0.73 ; $95 \% \mathrm{CI}: 0.6$ to 0.9 ) (Table 4 and Fig. 2).

C) Systemic oxygenation. This outcome was analyzed in 7 trials $^{30-}$ $34,36,37$, but the unity of measures was not always the same. In all the studies except one ${ }^{32}$, it was concluded that NO improved oxygenation. The metaanalysis data was consistent with the analyzed measurement. The weighted mean differences showed better results for the oxygenation index and $\mathrm{PaO}_{2}$ for those treated with NO (Table 5; Fig. 3).

D) Disturbances of the central nervous system. Three studies ${ }^{32,34,37}$ were selected, with 420 newborns. There was no difference between NOtreated and control groups (odds ratio: 0.83 ; $95 \%$ CI: 0.50 to 1.37 ) (Table 6; Fig. 4).

E) Development of chronic pulmonary disease during hospitalization. This meta-analysis included 2 trials $^{32,34}$ totaling 378 infants. There was no difference between groups for this outcome. Forty-six cases of chronic pulmonary disease were found, $30 / 217(11 \%)$ in the NO-treated group, and $17 / 161(14 \%)$ in the control group (odds ratio: 1.3 ; $95 \%$ CI: 0.69 to 2.46 ) (Table 7, Fig. 5).

\section{PPHN with congenital diaphrag- matic hernia}

\section{A) Death or ECMO requirement:}

These outcomes were analyzed in only one trial ${ }^{35}$, and both were considered as a single outcome. From the 53 patients studied, 28 were in the control group and 25 were in the NO-treated group. The rate for the control group was 0.82 and for those treated with $\mathrm{NO}$ was 0.96 (relative risk: $1.17 ; 35 \% \mathrm{CI}: 0.97$ to 1.41) (Table 8).

B) Systemic oxygenation: Two trials ${ }^{33,35}$ were selected, but the authors have published their data differently, so we could not assemble them in a unique meta-analysis. In one trial ${ }^{35}$, a subgroup of 10 patients with pulmonary hypoplasia did not have an improvement of oxygenation when com- 
Table 3 - Nitric oxide vs Conventional treatment: Death during hospitalization.

\begin{tabular}{lcc}
\hline & Results $(\%)$ & 95\% Confidence interval \\
\hline Control group & $0.12(12)$ & - \\
NO group & $0.11(11)$ & - \\
Relative risk & 1.03 & 0.62 to 1.72 \\
Odds ratio & 1.04 & 0.59 to 1.82 \\
\hline
\end{tabular}

Trial

$\begin{array}{ccccc}\text { Exp. } & \text { Contr. } & \text { OR } & \text { Weight } & \text { OR } \\ \text { N/N } & \text { n/N } & (\text { CI } 95 \%) & \% & (\text { CI 95\%) }\end{array}$

\begin{tabular}{|c|c|c|c|c|c|}
\hline Barefield 1996 & $2 / 9$ & $1 / 8$ & $\longrightarrow$ & 4.1 & $1.78[0.20,16.10]$ \\
\hline Davidson 1998 & $9 / 113$ & $1 / 41$ & & 5.6 & $3.27[0.43,24.99]$ \\
\hline ANNOS 1997a & $16 / 114$ & $20 / 121$ & - & 74.3 & $0.85[0.46,1.56]$ \\
\hline Roberts 1997 & $2 / 30$ & $2 / 28$ & & 7.9 & $0.93[0.14,6.19]$ \\
\hline Wessel 1997 & $2 \longdiv { 2 6 }$ & $2 / 23$ & & 8.1 & $0.88[0.14,5.79]$ \\
\hline Total (95\%Cl) & $31 / 292$ & $26 / 221$ & & 100.0 & $1.03[0.62,1.72]$ \\
\hline
\end{tabular}

Chi-square 2,05 $(\mathrm{df}=4)$

1

Favour treatment

Favour control

Figure 1 - Nitric oxide vs conventional treatement: death during hospitalization.

Table 4 - Nitric oxide vs Conventional treatment: Requirement for ECMO during hospitalization.

\begin{tabular}{lcc}
\hline & Results $(\%)$ & 95\% Confidence interval \\
\hline Control group & $0.50(50)$ & - \\
NO group & $0.33(33)$ & - \\
Relative risk & 0.73 & 0.60 to $0.90 *$ \\
Absolute risk reduction & $0.13(13)$ & 0.05 to 0.21 \\
Relative risk reduction & $0.26(26)$ & 0.10 to 0.40 \\
Number needed to treat & 8 & 4.74 to 22.22 \\
\hline$* \mathrm{P}<0.05$ & &
\end{tabular}

$\begin{array}{cccccc}\text { Trial } & \text { Exp. } & \text { Contr. } & \text { RR } & \text { Weight } & \text { RR } \\ & \text { n/N } & n / N & (C I 95 \%) & \% & (\text { CI 95\%) }\end{array}$

\begin{tabular}{|c|c|c|c|c|c|}
\hline Barefield 1996 & $6 / 9$ & $6 / 8$ & $\rightarrow$ & 5.2 & $0.89[0.48,1,64]$ \\
\hline Connfield 1997 & $6 / 12$ & $1 / 11$ & & 0.9 & $5.50[0.78,38.76]$ \\
\hline Davidson 1998 & $25 / 114$ & $14 / 41$ & & 17.0 & $0.64[0.37,1.11]$ \\
\hline NNOS 1997a & $44 / 114$ & $66 / 121$ & -1 & 52.8 & $0.71[0.53,0.94]$ \\
\hline Roberts 1997 & $12 / 30$ & $20 / 28$ & $\rightarrow-$ & 17.1 & $0.56[0.34,0.92]$ \\
\hline Wessel 1997 & $8 / 26$ & $8 / 23$ & & 7.0 & $0.88[0.40,1.98]$ \\
\hline Total (95\%Cl) & $101 / 305$ & $115 / 232$ & - & 100.0 & $0.73[0.60,0.90]$ \\
\hline
\end{tabular}

Figure 2 - Nitric oxide vs conventional treatement: requirement for ECMO during hospitalization. 
Table 5 - Measurements of systemic oxygenation of the seven selected studies.

\begin{tabular}{|c|c|c|}
\hline & Study Population & $\begin{array}{l}\text { Results } \\
\text { (95\% confidence interval) }\end{array}$ \\
\hline $\mathrm{PaO}_{2}$ (torr) at 30 and $60 \mathrm{~min}$ & $\begin{array}{l}\text { Control group: } 53 \\
\text { NO group: } 57\end{array}$ & $\mathrm{WMD}^{\mathrm{b}}: 53.18$ (44.8 a 61.4$)$ \\
\hline $\mathrm{OI}^{\mathrm{c}}$ at 30 and $60 \mathrm{~min}$ & $\begin{array}{l}\text { Control: } 94 \\
\text { NO group: } 171\end{array}$ & WMD: -12.17 (-14.4 a -9.9) \\
\hline $\begin{array}{l}\text { Number of improved cases } \\
\text { at } 30 \text { and } 60 \mathrm{~min}\end{array}$ & $\begin{array}{l}\text { Control group: } 28 \\
\text { NO group: } 30\end{array}$ & $\begin{array}{l}\text { RR }^{\mathrm{d}}: 7.47(1.9 \mathrm{a} 29.6) \\
\text { OR }^{\mathrm{e}}: 8.34(2.8 \mathrm{a} 25.1) \\
\text { ARR }^{\mathrm{f}}:-0.46(-0.6 \mathrm{a}-0.2) \\
\text { RRR }^{\mathrm{g}}:-6.47(-28.6 \mathrm{a}-0.9) \\
\text { NNT }^{\mathrm{h}}:-2.16(-3.8 \mathrm{a}-1.5)\end{array}$ \\
\hline $\mathrm{PaO}_{2}$ variation at 30 and $60 \mathrm{~min}$ & $\begin{array}{l}\text { Control group: } 121 \\
\text { NO group: } 114\end{array}$ & WMD: 48.50 (30.3 a 66.6) \\
\hline $\mathrm{OI}^{\mathrm{c}}$ variation at 30 and $60 \mathrm{~min}$ & $\begin{array}{l}\text { Control group: } 121 \\
\text { NO group: } 114\end{array}$ & WMD: -14.90 (-20.3 a -9.5) \\
\hline $\mathrm{OI}^{\mathrm{c}}$ reduction after end of treatment & $\begin{array}{l}\text { Control group: } 13 \\
\text { NO group: } 13\end{array}$ & WMD: -9.50 (-11.51 a -7.49) \\
\hline
\end{tabular}

a) Partial pressure of arterial oxygen; b) weighted mean difference; c) oxygenation index; d) relative risk; e) odds ratio; f) absolute risk reduction; g) relative risk reduction; h) number needed to treat.

$\begin{array}{ccclccc}\text { Exp. } & \text { Exp. } & \text { Contr. } & \text { Contr. } & \text { WMD } & \text { Weight } & \text { WMD } \\ \text { n } & \text { mean (sd) } & n & \text { mean (sd) } & \text { (CI 95\%) } & \begin{array}{c}\text { W } \\ \text { (CI 95\%) }\end{array}\end{array}$

\begin{tabular}{|c|c|c|c|c|c|c|c|}
\hline \multicolumn{8}{|c|}{ 10 em até 30 minutos } \\
\hline Barefield 1996 & 9 & $31.00(9.00)$ & 7 & $33.00(6.00)$ & & 8.9 & $-2.000[-9.371,5.371]$ \\
\hline Davidson 1998 & 114 & $19.00(11.00)$ & 41 & $24.00(14.00)$ & - & 21.4 & $-5.000[-9.737,-0.263]$ \\
\hline Roberts 1997 & 30 & $25.00(14.00)$ & 28 & $46.00(18.00)$ & $\checkmark$ & 6.9 & $-21.000[-29.340,-12.66]$ \\
\hline Subtotal $(95 \% \mathrm{Cl})$ & 153 & & 76 & & $\leftrightarrow$ & 37.2 & $-7.260[-10.856,-3.665]$ \\
\hline \multicolumn{8}{|c|}{ Chi square $13,26(\mathrm{df}=2)$} \\
\hline \multicolumn{8}{|c|}{10 de 30 a 60 minutos } \\
\hline Barefield 1996 & 7 & $23.00(7.00)$ & 7 & $38.00(6.00)$ & $\leftarrow$ & 10.3 & $-15.000\left[-21.830,-8.170^{\circ}\right.$ \\
\hline Day 1996 & 11 & $17.50(3.20)$ & 11 & $32.60(4.00)$ & $\triangleleft$ & 52.5 & $-15.100[-18.127,-12.07:$ \\
\hline Subtotal $(95 \% \mathrm{Cl})$ & 18 & & 18 & & $\triangleleft$ & 62.8 & $-15.084[-17.851,-12.311$ \\
\hline
\end{tabular}

Chi square $0,00(\mathrm{df}=1)$

Chi square $24,68(\mathrm{df}=4)$

Figure 3 - Nitric oxide vs conventional treatement: systemic oxygenation.

pared with the control group; but considering only the NO-treated group, the measurements were better after treatment in comparison with the baseline $\left(\mathrm{PaO}_{2}: 29 \pm \pm 3 \mathrm{~mm} \mathrm{Hg}\right.$ vs $45 \pm \pm 10$ $\mathrm{mm} \mathrm{Hg} ; \mathrm{P}<0.05)$. In the larger trial ${ }^{37}$, the authors did not find an improvement for this outcome (Table 9).

C) Disturbances of the central nervous system: The only study found ${ }^{37}$ showed no difference between the groups: $4 / 28$ (14\%) events in con- trol group and 4/25 (16\%) in NOtreated group (odds ratio: $1.14 ; 95 \%$ CI: 0.26 to 5.07 )

D) Development of chronic pulmonary disease: The same trial ${ }^{37}$ was again the only one to study this end- 
Table 6 - Nitric oxide and Conventional treatment: disturbances of the central nervous system.

\begin{tabular}{lcc}
\hline & Results $(\%)$ & 95\% Confidence interval \\
\hline Control group & $0.20(20)$ & - \\
NO group & $0.19(19)$ & - \\
Odds ratio & 0.83 & 0.50 to 1.37 \\
\hline
\end{tabular}

$\begin{array}{cccccc}\text { Trial } & \text { Exp } & \text { Control } & \text { OR } & \text { Weight } & \text { OR } \\ & n / N & n / N & (C I ~ 95 \%) & \% & (\text { CI 95\%) }\end{array}$

\begin{tabular}{|c|c|c|c|c|c|}
\hline Davidson 1998 & $23 / 97$ & $10 / 39$ & $\rightarrow$ & 33.7 & $0.90[0.38,2.14]$ \\
\hline NUNOS 1997a & $18 / 114$ & $19 / 121$ & -1 & 512 & $1.01[0.50,2.03]$ \\
\hline Wessel 1997 & $4 / 26$ & $8 / 23$ & & 15.1 & $0.36[0.10,1.30]$ \\
\hline Total $(95 \% \mathrm{Cl})$ & $45 / 237$ & $37 / 183$ & & 100.0 & $0.83[0.50,1.37]$ \\
\hline
\end{tabular}

Chi square $1,96(\mathrm{df}=2)$

1

Favour treatment

Favour control

Figure 4 - Nitric oxide vs conventional treatement: disturbances of the central nervous system.

Table 7 - Nitric oxide vs Conventional treatment: Development of chronic pulmonary disease during hospitalization.

\begin{tabular}{lcc}
\hline & Results (\%) & 95\% \\
\hline Control group & $0.11(11)$ & - \\
NO group & $0.14(14)$ & - \\
Relative risk & 1.26 & 0.72 to 2.24 \\
Odds ratio & 1.30 & 0.69 to 2.46 \\
Absolute risk reduction & $0.02(2)$ & -0.97 to 0.04 \\
Relative risk reduction & $0.27(27)$ & -1.24 to 0.28 \\
Number needed to treat & Not significant & - \\
\hline
\end{tabular}

\begin{tabular}{|c|c|c|c|c|c|}
\hline Trial & $\begin{array}{l}\operatorname{Exp} \\
\mathbf{n} / \mathbf{N}\end{array}$ & $\begin{array}{l}\text { Control } \\
n / N\end{array}$ & $\begin{array}{c}\text { OR } \\
\text { (CI 95\%) }\end{array}$ & $\begin{array}{c}\text { Weight } \\
\%\end{array}$ & $\begin{array}{l}\text { OR } \\
\text { (CI 95\%) }\end{array}$ \\
\hline Davidson 1998 & $15 / 103$ & $5 / 40$ & 7 & 36.8 & $1.19[0.42,3.39]$ \\
\hline RUNNOS 1997a & $15 / 114$ & $12 / 121$ & -5 & 63.2 & $1.37[0.62,3.06]$ \\
\hline Total ( $(95 \% \mathrm{Cl})$ & $30 / 217$ & $17 / 161$ & & 100.0 & $1.30[0.69,2.46]$ \\
\hline
\end{tabular}

Chi square $0,05(\mathrm{df}=1)$

\section{Favour treatment $\quad$ Favour control}

Figure 5 - Nitric oxide vs conventional treatement: development of chronic pulmonary disease during hospitalization. 
Table 8 - PPHN with congenital diaphragmatic hernia: Death or ECMO requirement.

\begin{tabular}{lcc}
\hline & Results $(\%)$ & 95\% Confidence interval \\
\hline Control group & $0.82(82)$ & - \\
NO group & $0.96(96)$ & - \\
Relative risk & 1.17 & 0.97 to 1.41 \\
Absolute risk reduction & $0.14(14)$ & -0.02 to 0.30 \\
Relative risk reduction & $0.17(17)$ & 0.03 to 0.41 \\
Number needed to treat & 7.19 & 3.33 to 43.48 \\
\hline
\end{tabular}

Table 9 - PPHN with congenital diaphragmatic hernia: Systemic oxygenation.

\begin{tabular}{|c|c|c|}
\hline & Increase in $\mathrm{PaO}_{2}$ torr & Decrease in oxygen index \\
\hline NO group ${ }^{a}$ & $7.80( \pm 19.80)$ & $-2.70( \pm 23.40)$ \\
\hline Control group ${ }^{a}$ & $1.10( \pm 7.60)$ & $4.00( \pm 14.80)$ \\
\hline$P$ value & 0.22 & 0.27 \\
\hline WMD $^{\mathrm{b}}$ ( $95 \%$ confidence interval $)$ & $6.70(-1.55$ to 14.95$)$ & $-6.70(-17.38$ to 3.98$)$ \\
\hline
\end{tabular}

${ }^{a}$ Media ( \pm standard deviation)

${ }^{\mathrm{b}}$ Weighed mean difference

point, and no benefit was demonstrated with inhaled NO (relative risk: 0.62 ; 95\% CI: 0.24 to 1.61$)$.

\section{DISCUSSION}

Infants without congenital diaphragmatic hernia

For the majority of intensive care unit trials, mortality is the most meaningful outcome because it is easily measured and clinically important ${ }^{38}$.

The results of this meta-analysis, involving 531 patients without diaphragmatic hernia, may appear to exclude any possible benefit from inhaled $\mathrm{NO}$ in reducing the mortality of infants with persistent pulmonary hypertension.

However the lower bound of the 95\% confidence interval-the one which suggests the largest benefit from treatment-was 0.59 , showing that clinically important benefits fall within the confidence interval, so the trial cannot definitely rule out the possibility that the treatment is beneficial for this outcome. Furthermore, although a population of 531 patients may seem expressive, the power of this metaanalysis would be nearest $30 \%$ (Type II error: 0.7) if the expected reduction in death rate with the use of $\mathrm{NO}$ was $30 \%$. This means that there would be a $70 \%$ chance that we wrongly accepted the null hypothesis and that we could not have detected the effect of inhaled NO on mortality, even if it may exist. The power would be greater if the baseline mortality was higher or if the sample was larger.

Therefore, it would be premature to definitely rule out inhaled NO from the management resources for PPHN because we have not found a reduction in mortality. In doing so, we might be giving up a "gray zone" intervention with great potential benefits ${ }^{38,39}$.

Mechanisms for suboptimal inhaled NO responses are: unsuspected structural heart disease; left ventricular dysfunction, decreased lung volume in association with pulmonary parenchymal disease, pulmonary edema, low concentrations of $\mathrm{NO}$ for the severity of the disease, paradoxical response to NO, worsening of the ventilation/perfusion ratio, cytotoxicity of $\mathrm{NO}$ and its metabolites, structural abnormalities of the pulmonary vascular tree, undiag- nosed alveolar capillary dysplasia or pulmonary hypoplasia, non-optimized hemodynamic and ventilatory support, and undetected biochemical abnormalities $^{23,31,32,36,37,40,42,43}$.

If we estimate mortality in the control group as $12 \%$, this means that $88 \%$ of the infants would survive. Therefore direct measures of quality of life have also clinically meaningful outcomes. In the same way, a lower requirement for invasive, potentially harmful, and expensive therapeutic procedures such as ECMO is also beneficial ${ }^{44 ; 45}$.

Systemic arterial oxygenation improved with NO treatment. Although physiologically relevant, to be considered a valid outcome, this response should correlate to a true clinical outcome and fully capture the treatment effect.

The pathophysiologic mechanisms of PPHN associated with $\mathrm{CDH}$ and the pharmacological actions of inhaled NO help to explain the reasons for the poor responses of these infants. In some patients, there was temporary improvement of systemic oxygenation, but even this positive result was not significant.

\section{Implications for Clinical Practice}

Inhaled NO appears to improve the outcome in hypoxemic-term and nearterm infants with PPHN. We do not consider it as the "magic bullet", but rather as a part of a strategy addressing the complex cardiopulmonary interactions that characterize this syndrome. One of the possible co-interventions is a rescue treatment with high frequency ventilation and/or exogenous surfactant, allowing the NO to contact most pulmonary areas, improving the ventilation/perfusion rate. Adjunctive therapy of hemodynamic support is also useful in the maintenance of systemic arterial pressure, an essential condition to change the right to left intracardiac shunting. Patients selected 
for inhaled NO treatment cannot have high degrees of structural pulmonary abnormalities (hypoplasia or alveolar capillary dysplasia) that could prevent the action of the gas. An adequate concentration of inhaled NO (probably between 5 and $20 \mathrm{ppm}$ ) must be used to achieve the best response in each clinical situation and to prevent the cytotoxic effects. The treatment must be initiated before structural pulmonary changes have developed ${ }^{40-43}$.

More clinical trials considering the above mentioned considerations must be performed.

With concentrations from 5 to 20 ppm, the potential toxic effects including methemoglobinemia and lung injury caused by $\mathrm{NO}_{2}$, peroxynitrite, and hydroxyl radical formation are minimal. Inhalation therapy with NO is less costly than ECMO; the cost for treating 3 patients with ECMO is equiva- lent to the costs of the system to deliver NO to several more patients.

In congenital diaphragmatic hernia, NO remains an unproved treatment. For these infants, when ECMO criteria are fulfilled, time must not be wasted with therapeutic treatments with NO that could postpone ECMO. Inhaled NO may be effective in neonates with hypoplastic lungs who need to be transported to an ECMO center. Some infants seem to have a better response when NO was used after a period with ECMO or in cases that developed postoperative pulmonary hypertension $^{44,45}$.

\section{CONCLUSIONS}

In the management of persistent pulmonary hypotension (PPHN) of term and near-term newborns without congenital diaphragmatic hernia $(\mathrm{CDH})$ or pulmonary hypoplasia, inhaled nitric oxide (NO) reduces requirements for extracorporeal membrane oxygenation (ECMO) and improves systemic oxygenation, but does not change mortality.

For infants with $\mathrm{CDH}$ or pulmonary hypoplasia, there were no differences between NO-treated and untreated groups in mortality, need for ECMO, or oxygenation.

The incidence of disturbances of the central nervous system (convulsions or hemorrhagic disorders) and development of chronic pulmonary disease during hospitalization were the same for the NO-treated group and the control group, regardless of whether the PPHN was or was not associated with $\mathrm{CDH}$ or pulmonary hypoplasia.
OLIVEIRA CAC e col. - Avaliação do uso do óxido nítrico no tratamento da hipertensão pulmonar persistente do recém-nascido: uma metanálise. Rev. Hosp. Clín. Fac. Med. S. Paulo 55 (4):145-154, 2000.

Objetivos: Avaliar o papel do óxido nítrico inalatório no tratamento da hipertensão pulmonar persistente do recém-nascido. Material e método: Busca bibliográfica informatizada para janeiro de 1990 a março de 1998 (MEDLINE, CURRENT CONTENTS e LILACS) complementada manualmente. Apenas ensaios clínicos contro- lados e randomizados foram selecionados. Intervenção: tratamento com óxido nítrico inalatório comparado com tratamento convencional. Desfechos: morte, necessidade de ECMO, oxigenação sistêmica, complicações em sistema nervoso central e doença pulmonar crônica. Qualidade metodológica: critério de escores, sendo treze a pontuação máxima. Resultados: Nos não portadores de hérnia diafragmática o óxido nítrico inalatório não reduziu a mortalidade, OR: 1,04 (IC 95\%: 0,59 a 1,82 ), mas diminuiu a necessidade de indicação de ECMO, RR: 0,73 (IC 95\%: 0,6 a 0,9) e melhorou a oxigenação sistêmica, diferença média ponderada (DMP) para $\mathrm{PaO} 2 \mathrm{em} 30 \mathrm{e}$ 60min: 53,18 (IC 95\%: 44,8 a 61,4) e DMP para IO em 30 e 60min: $-12,17$ (IC 95\%: -14,4 a -9,9). Nos portadores de hérnia diafragmática, não houve melhora da oxigenação arterial, nem redução da mortalidade ou da necessidade de ECMO, RR: 1,17 (IC 95\%: 0,97 a 1,41). A incidência de complicações neurológicas e de doença pulmonar foram semelhantes para os dois grupos.

DESCRITORES: Oxido nítrico. Recém nascido. Hipertensão pulmonar. ECMO. Metanálise. 


\section{REFERENCES}

1. GERSONY WM, MORISHIMA HO, DANIEL SS et al. - The hemodynamic effects of intrauterine hypoxia: an experimental model in newborn lambs. J Pediatr 1976; 89: 631-5.

2. ABMAN SH \& KINSELLA JP - Inhaled nitric oxide therapy of pulmonary hypertension and respiratory failure in premature and term neonates. Adv Pharmacol 1995; 34:457-75.

3. WALSH-SUKYS MC - Persistent pulmonary hypertension of the newborn. The black box revisited. Clin Perinatol 1993; 20:127-43.

4. CORNFIELD D - Effects of birth-related stimuli on L-argininedependent pulmonary vasodilatation in ovine fetus. Am J Physiol 1992; 262:1474-81.

5. FURCHGOTT RF - Introduction to EDRF research. J Cardiovasc Pharmacol 1993; 22:supl.7, p.s1-2.

6. HAMMERMAN C LASS N \& STRATES E - Prostanoids in persistent pulmonary hypertension. J Pediatr 1987;39:470-2

7. KINSELLA JP \& ABMAN SH - Recent developments in the pathophysiology and treatment of persistent pulmonary hypertension of the newborn. J Pediatr 1995; 126:853-64.

8. ROBERTS JD \& SHAUL PW - Inhaled nitric oxide for treatment of pulmonary artery hypertension in the newborn and infant. Crit Care Med 1993; 21 suppl: s374.

9. RUSS DR. \& WALKER RB - Role of nitric oxide in vasopressinergic pulmonary vasodilatation. Am J Physiol 1992; 262:743-7.

10. SOIFER SJ - Pulmonary hypertension: physiologic or pathologic disease? Crit Care Med 1993; 21(suppl):s370-4.

11. SPITZER AR, DAVIS J, CLARCKE WT - Pulmonary hypertension and persistent fetal circulation in the newborn. Clin Perinatol 1988; 15:389-413.

12. BALLARD RA \& LEONARD CH - Developmental follow-up of infants with persistent pulmonary hypertension of the newborn. Clin Perinatol 1984; 11:737-44.

13. DAVIDSON D - Inhaled nitric oxide for neonatal pulmonary hypertension. Am Rev Respir Dis 1993; 147:1078-9.

14. DAVIDSON D - Inhaled nitric oxide trials: "Vive la différence". Pediatrics 1996; 97: 4389.

15. GEGGEL RL \& REID LM - The structural basis of PPHN. Clin Perinatol 1984; 11:525-49.

16. FERRARA B, JOHNSON DE, CHANG P-N et al. - Efficacy and neurologic outcome of profound hypocapneic alkalosis for treatment of persistent pulmonary hypertension. J Pediatr 1984; 105:457-61.

17. HAMMERMAN C, YOUSEFZADEH D, CHOI J-H et al. - Persistent pulmonary hypertension of the newborn: managing the unmanageable. Clin Perinatol 1989;16:137-56.

18. MILNER DA - Nitric oxide. Eur J Pediatr 1994; 153:7-11.

19. FURCHGOTT RF \& ZAWADZKI JV - The obligatory role of endothelial cells in the relaxation of arterial muscle by acetylcholine. Nature 1980; 288:376-6.
20. DUSTING GJ, READ MA \& STEWART AG - Endothelium-derived relaxing factor released from cultured cells: differentiation from nitric oxide. Clin Exp Pharmacol Physiol 1988; 15:83-91.

21. KIECHLE FL \& MALINSKI T - Nitric oxide. Biochemistry, pathophysiology, and detection. Am J Clin Pathol 1993; 100: 56775 .

22. MONCADA S - The firs Robert Furchgott lecture: from endotheliumdependent relaxation to the L-arginine: NO pathway. Blood Vessels 1990; 27:208-17.

23. CORNFIELD D \& ABMAN HS - Inhalation nitric oxide in pulmonary parenchymal and vascular disease. J Lab Clin Med 1996;127:530-9.

24. PEPKE-ZABA J, HIGENBOTTAM TW, DINH-XUAN AT et al. Inhaled nitric oxide as a cause of selective pulmonary vasodilation in pulmonary hypertension. Lancet 1991;338:1173-4.

25. FROSTELL CG, FRATACCI M-D, WAIN JC et al. - Inhaled nitric oxide: a selective pulmonary vasodilator reversing hypoxic pulmonary vasoconstriction (published erratum appears in circulation). Circulation 1991; 83:2038-47.

26. KINSELLA JP, TOWES WH, HENRY D et al. - Selective and sustained pulmonary vasodilation with inhalational nitric oxide therapy in a child with idiopathic pulmonary hypertension. J Pediatr 1993; 122: 803-6.

27. KINSELLA PJ, NEISH SR, DUNBAR D et al. - Clinical responses to prolonged treatment of persistent pulmonary hypertension of the newborn with low doses of inhaled nitric oxide. J Pediatr 1993; 123:103-8.

28. ABMAN SH \& KINSELLA JP - Inhaled nitric oxide for persistent pulmonary hypertension of the newborn: the physiology matters. J Pediatr 1995;11: 53-5.

29. HEYLAND DK, COOK DJ, BMATH DK et al. - Maximizing oxygen in critical ill patients: a methodological appraisal of evidence. Crit Care Med 1996; 24:517-24.

30. BAREFIELD SE, KARLE VA, PHILIPS JB et al. - Inhaled nitric oxide in term infants with hypoxemic respiratory failure. J Pediatr 1996; 129:279-86

31. CORNFIELD ND, GUIANG S, DE REGNIER et al. - Randomized controlled trial of low dose inhalational nitric oxide in persistent pulmonary hypertension of the newborn. Pediatr Res 1997; 41:144A.

32. DAVIDSON D, BAREFIELD ES, KATTWINKEL J et al. - Inhaled nitric oxide for the early treatment of persistent pulmonary hypertension of the term newborn: a randomized, double-masked, placebo-controlled, dose-response, multicenter study. Pediatrics 1998; 101:325-34.

33. DAY RW, LYNCH JM, WHITE KS et al. - Acute response to inhaled nitric oxide in newborns with respiratory failure and pulmonary hypertension. Pediatrics 1996; 98:698-705.

34. THE Neonatal Inhaled Nitric Oxide Study Group - Inhaled nitric oxide in full-term and nearly full-term infants with hypoxic respiratory failure. N Engl J Med 1997;336:597-604. 
35. THE NEONATAL INHALED NITRIC OXIDE STUDY GROUP Inhaled nitric oxide and hypoxic respiratory failure in infants with congenital diaphragmatic hernia. Pediatrics 1997; 99:.838-45.

36. ROBERTS JD, FINEMAN JR, MORIN FC et al. - Inhaled Nitric Oxide Study Group. Inhaled nitric oxide avaliação do uso do óxido nítrico no tratamento da hipertensão pulmonar persistente do recémnascido: uma metanáliseand persistent pulmonary hypertension of the newborn. N Engl J Med 1997;336:605-10.

37. WESSEL LD, ADATIA I, VAN MARTER LJ et al. - Improved oxygenation in a randomized trial Of Inhaled nitric oxide for persistent pulmonary hypertension of the newborn. Pediatrics 1997;100:1-14.

38. DOIG G - Interpreting and using clinical trials. Crit Care Clin 1998;14:513-24.

39. CASSIERE HA, GROTH M \& NIEDERMAN MS - Evidence-based medicine: the Wolf in sheep's clothing. Yr Bk Intens Care Emerg Med 1997; 744-9.
40. SHAH NS, NAKAYAMA DK \& JACOB TD - Efficacy of inhaled nitric oxide in oleic acid-induced acute lung injury. Crit Care Med 1997;25(1):153-8.

41. KINSELLA JP \& ABMAN SH - Controversies in the use of inhaled nitric oxide therapy in The newborn. Clin Perinatol 1998;25:203-17.

42. STEINHORN RH, COX PN, FINEMAN JR et al. - Inhaled nitric oxide Enhances oxygenation but not survival in infants with alveolar capillary dysplasia. J Pediatr 1997;130:417-22.

43. TURBOW R, YANG L, SILLS J et al. - Variable oxygenation response to inhaled nitric oxide in severe persistent pulmonary hypertension of the newborn. Acta Paediatr 1995;84:1305-8.

44. KANTO WP - A decade of experience with neonatal extracorporeal membrane oxygenation. J Pediatr 1994;124:335-47.

45. SMITH J \& KIRSTEN GF - Persistent pulmonary hypertension of the neonate in a developing country - does extracorporeal membrane oxygenation have a role to play. S Afr Med J 1993; 83:742-5.

Received for publication on the $03 / 07 / 00$ 


\section{NEWS}

\section{1 ${ }^{\circ}$ CONGRESSO BRASILEIRO DE PEDIATRIA}

07 to $13 / 10 / 00$

Centro de Convenções de Fortaleza-CE

Tel: (85) 2615849

E-mail: socep@roadnet.com.br

\section{$6^{\circ}$ CONGRESSO PAULISTA DE OBSTETRÍCIA E GINECOLOGIA DA SOGESP}

11 to $14 / 11 / 00$

Centro Têxtil de São Paulo-SP

Phone: (11) 8847654

XIII CONGRESSO MUNDIAL DE PSIQUIATRIA DINÂMICA II PRÊMIO GÜNTER AMMON

13 to $17 / 03 / 01$

Berlin - Germany

Tel: 0049/89/6427230

Fax: 0049/89/64272395

$3^{\text {nd }}$ ANNUAL MEDICAL-SCIENTIFIC CONFERENCE AMERICAN SOCIETY OF ADDICTION MEDICINE (ASAM)

19 to 22/04/01

Los Angeles, CA

Web site: www.asam.org 